\title{
Complete heart block in a 5-year-old child with varicella and acute thrombocytopenic purpura
}

\author{
Arani Sridhar, ${ }^{1}$ Anil Sapare, ${ }^{1}$ Srinivas Parepalli,, Jonathan Acheson² \\ ${ }^{1}$ Children's Hospital, Leicester Royal Infirmary, Leicester, UK; \\ 2Emergency Department, Leicester Royal Infirmary, Leicester, UK
}

Correspondence to Dr Arani Sridhar, arani.sridhar@uhl-tr.nhs.uk

\section{DESCRIPTION}

A 5-year-old Caucasian male presented to the Children's Emergency Department with epistaxis, bleeding from the dental extraction site and a widespread purpuric rash, secondary to acute idiopathic thrombocytopenia. Two days prior to this, he developed a generalised chickenpox rash. While in the department it was noted that his heart rate ranged between 50 and 60 beats per min, he was otherwise haemo-dynamically stable with a normal blood pressure and oxygen saturations in air. He had a short systolic murmur grade $2 / 6$ at the left sternal border. He had no clinical evidence of myocarditis or heart failure. He had extensive generalised petechiae and purpuric rash (figure 1) secondary to acute thrombocytopenia presumed to be due to varicella infection. Apparently he was healthy prior to this admission. There was no history of maternal lupus. An ECG was performed which showed complete heart block (figure 2). He was admitted to the high dependency unit for close overnight monitoring. The presumed diagnosis was complete heart block secondary to varicella infection. ${ }^{1} 2$ The initial investigation showed normal electrolytes, calcium, phosphate, glucose and magnesium levels. The full blood count showed a normal haemoglobin and white cell count. But the platelet count was low that is, $13 \times 10^{9} / 1$. The platelet count normalised within 10 days without any intervention. The antinuclear antibody titres and the autoimmune screen were negative. Maternal autoimmune screen was negative. The echocardiogram showed a structurally normal heart and follow-up $24 \mathrm{~h}$ tape showed persistence of complete heart block. Following these investigations a diagnosis of congenital complete heart block was made. On followup after 6 months his heart rate remains between 50 and 60 beats per min, but he remains asymptomatic without any intervention. The need for a pacemaker is being considered on follow-up. The incidental finding of complete heart block was congenital in aetiology with no association with varicella infection or acute thrombocytopenia. This case highlights that asymptomatic late-presenting congenital complete heart block must be considered as a differential diagnosis in children presenting with asymptomatic bradycardia to the emergency department.

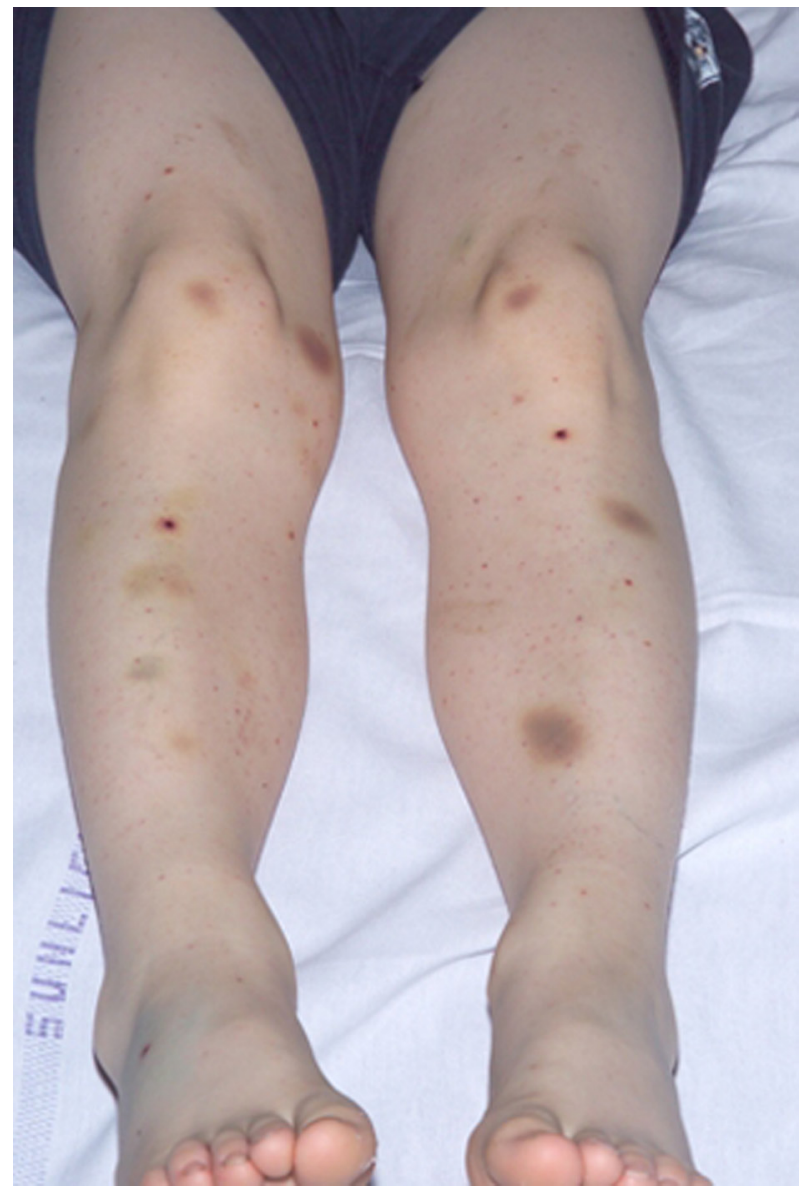

Figure 1 The lower limbs of the patient showing healing varicella lesions along with petechiae and purpura due to acute thrombocytopenic purpura. 


\section{BMJ Case Reports}

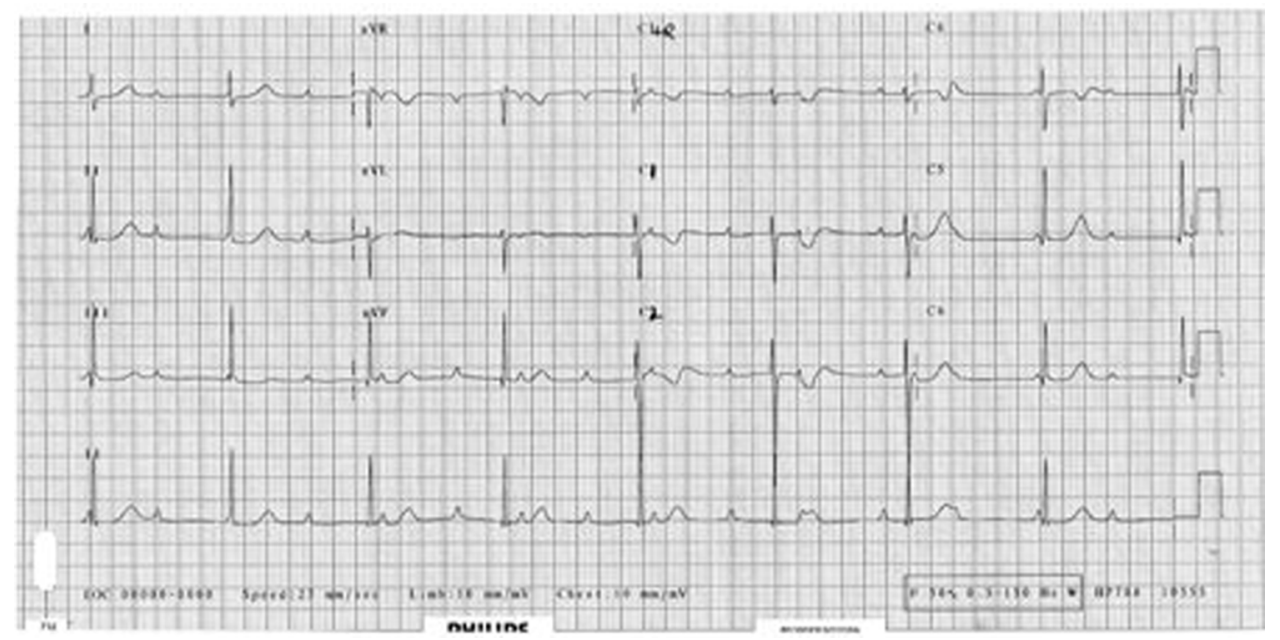

Figure 2 The ECG of the patient showing complete heart block.

Acknowledgements Dr Abdul Duke and Dr F BuLock, Consultant Paediatric Cardiologists, Glenfield Hospital, Leicester.

Competing interests None.

Patient consent Obtained.

\section{REFERENCES}

1. Rich R, Mclean M. Complete heart block in a child with varicella. Am J Emerg Med 1993;11:602-5

2. Ettedgui JA, Ladusans E, Bamford M. Complete heart block as a complication of varicella. Int J Cardiol 1987;14:362-5.

This pdf has been created automatically from the final edited text and images.

Copyright 2012 BMJ Publishing Group. All rights reserved. For permission to reuse any of this content visit http://group.bmj.com/group/rights-licensing/permissions.

BMJ Case Report Fellows may re-use this article for personal use and teaching without any further permission.

Please cite this article as follows (you will need to access the article online to obtain the date of publication).

Sridhar A, Sapare A, Parepalli S, Acheson J. Complete heart block in a 5-year-old child with varicella and acute thrombocytopenic purpura. BMJ Case Reports 2012;10.1136/bcr.10.2011.4985, Published XXX

Become a Fellow of BMJ Case Reports today and you can:

- Submit as many cases as you like

- Enjoy fast sympathetic peer review and rapid publication of accepted articles

- Access all the published articles

- Re-use any of the published material for personal use and teaching without further permission

For information on Institutional Fellowships contact consortiasales@bmjgroup.com

Visit casereports.bmj.com for more articles like this and to become a Fellow 